\title{
RELATIONSHIP BETWEEN VITAMIN D, CALCIUM, PARATHYROID HORMONE AND ALKALINE PHOSPHATASE AMONG PATIENTS INVESTIGATED FOR VITAMIN D
}

\author{
JAMAL BASHER MOHAMMAD \\ College of Medicine, University of Duhok, Kurdistan Region-Iraq
}

(Received: August 23, 2021; Accepted for Publication: October 17, 2021)

\begin{abstract}
INTRODUCTION: Vitamin D deficiency causes rickets in young children and Osteomalacia in adults.

Parathyroid hormone (PTH) secretion, Calcium level and Alkaline phosphatase (ALP), elevated in cases of low level of VD. This study to detect the relationship between serum VD, (PTH), calcium and ALP. Serum 25OHD is regarded as the best indicator of VD status.

METHODS: The current study is a retrospective descriptive study in Azadi Teaching Hospital- Duhok Governorate - Kurdistan Region / Iraq. Out of 870 patients were included in the study. All VD requests were analysed, Calcium, ALP, PTH, and phosphate were recorded.

RESULTS: Fifty-nine percent of the requests were for females, and $27.9 \%$ of the included patients were receiving VD supplementation. The mean values for serum $250 H D$ and PTH levels were $34.5 \mathrm{nmol} /$ $\mathrm{L}$ (13.8ng/ml) and 53.4pg / $\mathrm{ml}$ respectively.

Serum 25OHD was below $25 \mathrm{nmol} / \mathrm{L}$ in (227 / 870) $26.09 \%$, between $25-50 \mathrm{nmol} / \mathrm{L}$ in (391/ 870) $44.94 \%$, and $>50$ in $(252 / 870) 28.96 \%$.

Out of 227 patients with VD deficiency $(<25 \mathrm{nmol} / \mathrm{L})$, only 1(0.44\%) had hypocalcaemia, $28(12.33 \%)$ had abnormal high ALP, $109(48 \%)$ had abnormal high PTH. Out of 252 patients with VD level $>50 \mathrm{nmol}$ / $\mathrm{L}, 63(25 \%)$ were found to have high PTH, $21(8.33 \%)$ with high ALP, hypocalcaemia were found in $1(0.39 \%)$ and low phosphate were found in $7(2.77 \%)$ of the patients.

Out of 391 patients with normal VD $(<25.1-50 \mathrm{nmol} / \mathrm{L})$, only $3(0.76 \%)$ had hypocalcaemia, 30 (7.67\%) had abnormal high ALP, and 154 (39.38\%) had abnormal high PTH.

CONCLUSION: A normal Calcium level, ALP and/or PTH will not exclude 25OHD deficiency and measurement of 25OHD should be performed whenever VD deficiency is expected.
\end{abstract}

KEYWORDS: Vitamin D, Alkaline Phosphatase, Parathyroid hormone, Calcium

\section{INTRODUCTION}

$\mathbf{V}$ itamin $D$ is a necessary fat-soluble vitamin for calcium metabolism and homeostasis ${ }^{1}$. These problems are major public health issues worldwide, many researchers have revealed high prevalence of VD deficiency globally $^{2,3}$. However, VD deficiency worldwide is not clear, as there is lacking of data from some countries. About 1 billion person have low D concentrations and this is revealed in all ethnicities and age groups ${ }^{1}$.Sufficient VD level is necessary for bone health. When VD decrease causes Rickets in young children and Ostemalacia in adults ${ }^{4}$. However, non-skeletal conditions such as cancer, autoimmune diseases, psychiatric problems and metabolic syndrome were all reported to be related with VD deficiency ${ }^{5}$. Serum 25OHD is regarded to be the best indicator of VD status. Low VD may be associated with low corrected calcium, elevated alkaline phosphatase and secondary hyperparathyroidism. No universal agreement has been reached at which concentration represent normal. WHO consider VD insufficiency to be less than $50 \mathrm{nmol} / \mathrm{L}^{6}$. However, some researchers considered that serum 25OHD concentration of $75 \mathrm{nmol} / \mathrm{L}$ should be used instead because serum PTH showed plateau at this level ${ }^{7,8}$.

The present study viewed to detect the natural relationship between serum 25OHD, parathyroid PTH, calcium and ALP and to determine if 25OHD deficiency can be effectively excluded if no abnormalities found in calcium profile result.

\section{METHODS}

The current study is performed in Azadi General Teaching Hospital as a retrospective descriptive study. We audited all vitamin D requests analysed over March to May 2018. Cognos Imprometu (IBM Business software) was used to identify the vitamin $D$ requests. This is software required to interface with the 
laboratory information management system (APEX) for which a query is written in order to extract test codes and results. All requests were reviewed in APEX and corrected calcium (CCA), alkaline phosphatase (ALP), phosphate, PTH and estimated glomerular filtration rate (eGFR) were recorded. ALP (coefficient of variation $(\mathrm{CV})<2 \%$ at 57 and $203 \mathrm{IU} / \mathrm{L}), \mathrm{CCA}$ (calcium $\mathrm{CV}<2 \%$ at 1.55 and $3.22 \mathrm{mmol} / \mathrm{L}, \mathrm{PO} 4$ $(\mathrm{CV}<3 \%$ at 0.67 and $2.05 \mathrm{mmol} / \mathrm{L})$ and albumin (using $\mathrm{BCP}$ reagent, $\mathrm{CV}=2.7 \%$ at $27.4 \mathrm{~g} / \mathrm{L}$ and $1.0 \%$ at $46.2 \mathrm{~g} / \mathrm{L})$ were analysed using chemistries available on Roche instruments 8000 . The formula used for CCA was adjusted $=$ total $-(0.014 *$ albumin $)+0.62$, derived according to recommendations made by Barth and colleagues5. PTH was analysed by Roche chemiluminescent immunoassay PTH assay (CV $<3 \%$ at 22 and $123 \mathrm{ng} / \mathrm{L}$ ). 25OHD was analysed by a previously described HPLC method 6 , with an intra- and inter-assay CV of $2.5 \%$ and $6.9 \%$ respectively.

As currently defined in our laboratory, $25 \mathrm{OHD}$ less than $25 \mathrm{nmol} / \mathrm{L}$ is considered as deficient and treatment is required, between 25 -
$50 \mathrm{nmol} / \mathrm{L}$ is associated with an increased disease risk and treatment is usually required and $>50 \mathrm{nmol} / \mathrm{L}$ is sufficient. PTH reference range is between $10-60 \mathrm{pg} / \mathrm{ml}$. Reference ranges for calcium, phosphate and ALP are $2.10-2.55$ $\mathrm{mmol} / \mathrm{L}, 0.7-1.4 \mathrm{mmol} / \mathrm{L}$ and 35 - $104 \mathrm{U} / \mathrm{L}$ respectively. Data were analysed using Microsoft Excel 2003.

\section{RESULTS}

Patients known to have hypoparathyroidism, primary hyperparathyroidism, eGFR less than 35 were excluded and those who were receiving oral calcitriol or alfacalcidol were also excluded. A total of 870 patients with a mean age of 46 years were included in the study, 59\% of the requests were for females, (243/ 870) $27.9 \%$ of the patients were receiving VD supplement.

The mean values for serum 25OHD and PTH levels were $34.5 \mathrm{nmol} / \mathrm{L}(13.8 \mathrm{ng} / \mathrm{ml})$ and 53.4 $\mathrm{pg} / \mathrm{ml}$, respectively. Serum $250 H D$ was below $25 \mathrm{nmol} / \mathrm{L}$ in (227 / 870) $26.09 \%$, between 25 $50 \mathrm{nmol} / \mathrm{L}$ in (391/ 870) $44.94 \%$, and $>50$ in (252 / 870) $28.96 \%$.

Table( 1):- Demographics of data

\begin{tabular}{cc}
\hline Total number & $\mathbf{8 7 0}$ \\
\hline Female (\%) & $59 \%$ \\
\hline Median age (year) & 46 \\
\hline $\begin{array}{c}\text { Patients on vitamin D supplementation } \\
<25 \mathrm{nmol} / \mathrm{L}\end{array}$ & $243(27.9 \%)$ \\
\hline $25.1-50 \mathrm{nmol} / \mathrm{L}$ & $227(26.09 \%)$ \\
\hline$\geq 50.1 \mathrm{nmol} / \mathrm{L}$ & $391(44.94 \%)$ \\
\hline
\end{tabular}

Out of 227 patients with VD deficiency (< $25 \mathrm{nmol} / \mathrm{L})$, only $1(0.44 \%)$ had hypocalcaemia, $28(12.33 \%)$ had abnormal high ALP, 109 (48\%) had abnormal high PTH. Out of 252 patients with VD level > 50nmol / L, 63 (25\%) were found to have high PTH, 21 (8.33\%) with high ALP, hypocalcaemia were found in $1(0.39 \%)$ and low phosphate were found in $7(2.77 \%)$ of the patients .

Out of 391 patients with normal VD (25.1 50 nmol / L), only $3(0.76 \%)$ had hypocalcaemia, 30 (7.67\%) had abnormal high ALP, 154 (39.38\%) had abnormal high PTH.

Table (2): -Frequency of abnormalities in corrected calcium, ALP and PTH

\begin{tabular}{cccc}
\hline \multirow{2}{*}{ Parameters } & \multicolumn{3}{c}{ Patients with $25 \mathrm{OHD}$} \\
\cline { 2 - 4 } & $\begin{array}{r}<25 \mathrm{nmol} / \mathrm{L} \\
\text { No. }(227)\end{array}$ & $\begin{array}{c}25.1-50 \mathrm{nmol} / \mathrm{L} \\
\text { No. }(391)\end{array}$ & $\begin{array}{c}>50.1 \mathrm{nmol} / \mathrm{L} \\
\text { No. }(252)\end{array}$ \\
\hline Low Ca+2 & $1(0.44 \%)$ & $3(0.76 \%)$ & $1(0.39)$ \\
\hline Raised ALP & $28(12.33 \%)$ & $30(7.67 \%)$ & $21(8.33 \%)$ \\
\hline Raised PTH & $109(48.0 \%)$ & $154(39.38 \%)$ & $63(25.0)$ \\
\hline Low Phosphate & $5(2.2)$ & $14(3.58)$ & $7(2.77 \%)$ \\
\hline
\end{tabular}




\section{DISCUSSION}

Vitamin D deficiency is common in all ethnic group which may symptomatic or asymptomatic 16. Measurement of 25OHD is the most dependable indicator of vitamin D status .

When 25OHD concentration falls, gut absorption of calcium decline and PTH levels rise $^{4}$. There were many reports that claimed 25OHD deficiency of hypophosphatemia (3.5\%). Similarly, calcium and ALP were not found to be a good indicator for VD status.

Haarburger and colleagues found that low 25OHD concentrations can be seen even when PTH and calcium are within the reference range $^{12}$. They found no relation between 25OHD and PTH levels. This is consistent well with our data. Hashemipour et al, ${ }^{13}$ suggested that routine biochemistry can be used to the development metabolic bone disease as a result of VD deficiency. The sensitivity for at least one biochemical variable (calcium, phosphorus, or ALP) for the detection of severe, moderate, and mild VD deficiency was $24.2 \%, 13.8 \%$, and $6 \%$ respectively. They reported that if $25 \mathrm{OHD}$ level was cannot be reliably diagnosed based on routine biochemical investigations in adults and we have confirmed this in our population ${ }^{11}$. In this cohort, we found no correlation between $25 \mathrm{OHD}$ and PTH levels and only $48 \%$ of the patients with VD deficiency had elevated PTH. Low VD $<25 \mathrm{nmol} / \mathrm{L}$ was recorded with only 1 case of hypocalcaemia and levels between 25 $50 \mathrm{nmol} / \mathrm{L}$ were associated with 3 cases of hypocalcaemia $(0.76 \%)$ and 14 cases reduced to less than $25 \mathrm{nmol} / \mathrm{L}$, the effects of VD deficiency on calcium and phosphate levels were more obvious.

Wang et al. ${ }^{14}$ have reported that the relationship between biochemical tests and 25OHD concentrations may be affected by genetic determinants. They found that variation near genes encoding 25-hydroxylase CYP2R1, 7-dehydrocholesterol reductase and the degradation enzyme CYP24A1 affect VD status.
In a cohort study of 84 patients seen in Bradford with 25OHD concentrations $<25 \mathrm{nmol}$ / L and elevated PTH, it has been found that $66 \%$ had normal calcium, $81 \%$ normal PO4 and $29 \%$ normal ALP $^{15}$. This study suggested that for individuals with a high prevalence of VD deficiency or osteomalacia, biochemical assessment of suspected cases should include measurement of PTH, Calcium, creatinine, and full blood count and endomysial antibodies.

\section{CONCLUSION}

25OHD deficiency may be associated with poor PTH response. Absence of abnormal calcium, ALP, phosphate or PTH will not exclude 25OHD deficiency and measurement of 25OHD should be offered if VD deficiency is suspected clinically.

\section{REFERENCES}

Holick MF, Chen TC. Vitamin D deficiency: a worldwide problem with health consequences. Am. J. Clin. Nutr. 2008; 87(4):1080-86.

Mithal A, Wahl DA, Bonjour JP, Burckhardt P, Dawson-Hughes B, Eisman JA, El-Hajj Fuleihan G, Josse RG, Lips P, Morales-Torres J. IOF Committee of Scientific Advisors (CSA) Nutrition Working Group, Global vitamin D status and determinants of hypovitaminosis D. Osteoporos. Int. 2009; 20(11):1807-20.

van Schoor NM, Lips P. Worldwide vitamin D status. Best Pract. Res. Clin. Endocrinol. Metab. 2011; 25(4):671-80.

Holick MF. Vitamin D deficiency. N Eng J Med 2007; 357 (3): 266-81.

World Health Organization Scientific Group on the Prevention and Management of Osteoporosis 2003 Prevention and management of osteoporosis: report of a WHO scientific group. Geneva: World Health Organization.

Dawson-Hughes B, Heaney RP, Holick MF, Lips P, Meunier PJ,Vieth R 2005 Estimates of optimal vitaminDstatus. Osteoporos Int16:713-16. 
Holick MF. VitaminDdeficiency.NEngl J Med 2007; 357:266-81.

Barth JH, Fiddy JB, Payne RB. Adjustment of serum total calcium for albumin concentration: effects of non-linearity and of regression differences between laboratories. Ann Clin Biochem. 1996; 33: 55-58.

Mawer EB, Hann TJ, Berry JL, Davies M. Vitamin D metabolism in patients intoxicated with ergocalciferol. Clinical science London England. 1979; 68: 135-41.

Consensus Vitamin D Position Statement [internet]. 2010; [cited 2012 May 08].

Sahota O, Mundey MK, San P, et al. The relationship between vitamin D andparathyroid hormones: calcium homeostasis, bone turnover, and bone mineral densityin postmenopausal women with established osteoporosis. Bone. 2004; 35:312-19.

Haarburger D, Hoffman M, Erasmus RT and Pillay TS. Relationship between vitamin D, calcium and parathyroid hormone in Cape Town. J Clin Pathol. 2009; 62: 567-69.

Hashemipour S, Larijani B, Adibi H et al. The status of biochemical parameters in varying degrees of vitamin D deficiency. J Bone Miner Metab. 2006; 24: 213-18.

Wang TJ, Zhang F, Richards JB et al. Common genetic determinants of vitamin D insufficiency: a genome-wide association study. Lancet. 2010; 376: 180 - 88.

Peacey S. Routine Biochemistry in suspected vitamin D deficiency. J R Soc Med. 2004; 97: 322-25.

Das G, Crocombe S, McGrath M, Berry JL and Mughal MZ. Hypovitaminosis D among healthy adolescent girls attending an inner city school. Arch Dis Child. 2006; 91: 569-72.

oxfordOxford Textbook of Endocrinology, Oxford University Press 2002. Editors John A. H. Wass and Stephen M. Shalet.

$$
\text { العلاقه بين فيتامين د , الكاسيوم , هرمون الغده الدرقيه , الفوسفاتيز القلوي بين المرضى للكشف عن فيتامين د }
$$

نقص فيتامين د يسبب لين العظام عند الاطفال وهشاشة العظام عند البالغين. ان افراز هرمون الغده الدرقيه (PTH ) , مستوى الكالسيوم والفوسفاتيز القلوي ( ALP ) يتغير في حالات قلة مستوى فيتامين د د

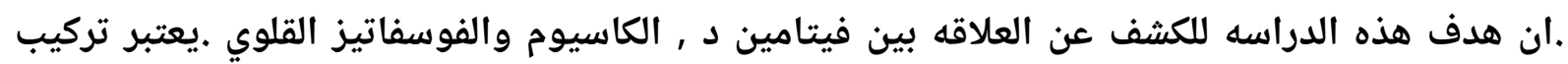
(25OHD) الطرائق:

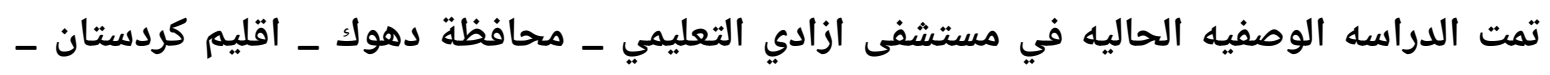
العراق وشملت الدراسه •AV مريضا تم فحصهم وتسجيل مستوى فيتامين د , الكالسيوم, الفوسفاتيز القلوي , أهرمون الغده الدرقيه والفوسفيت.

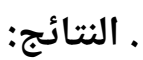


ان \% \% من المرضى كانو من الاناث و \%rV,9 من المرضى يعالجون بمكملات فيتامين دـ ـ اما بقية

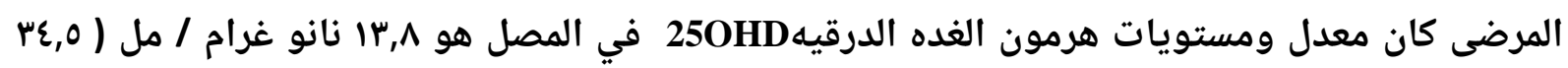

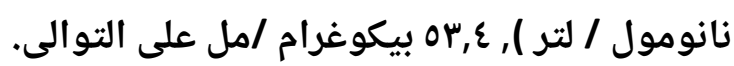

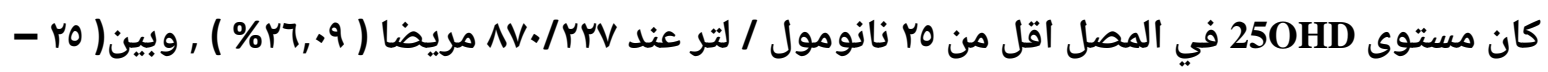

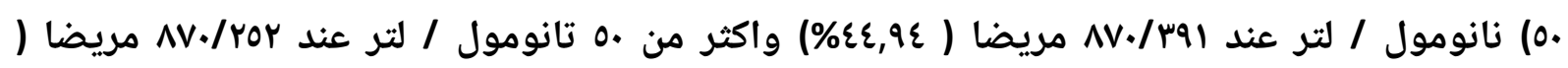

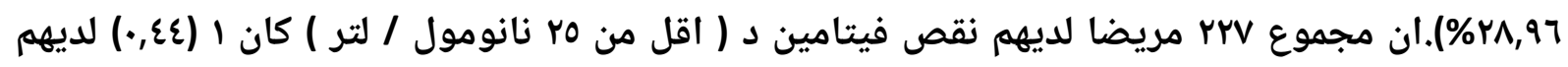

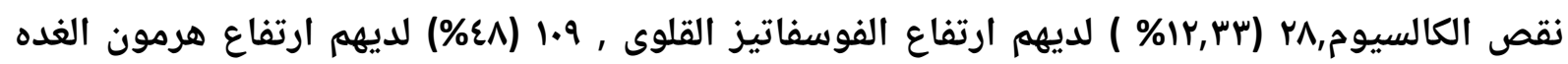

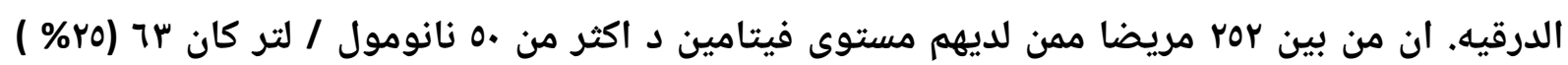

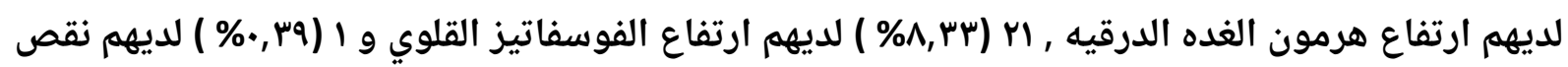

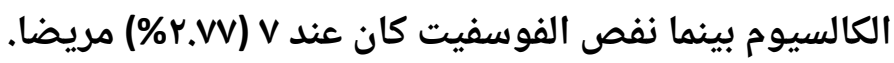

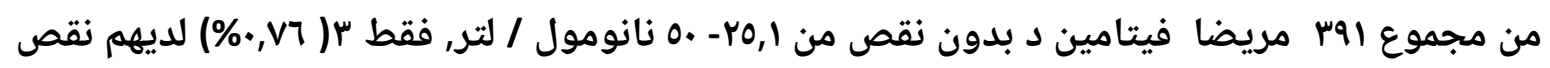

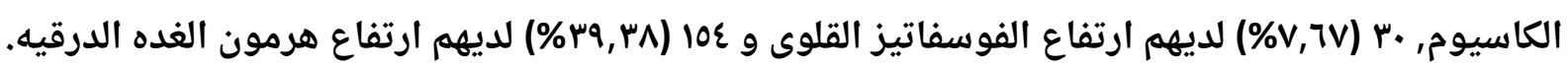

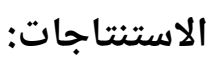
ان مستوى الكالسيوم الطبيعي , الفوسغاتيز القلوي مع او هرمون الغده الدرقيه لايستبعد نقص فئنس

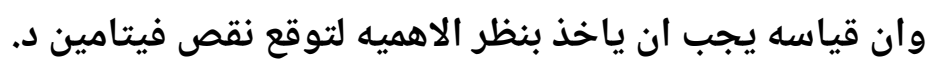
الكلمات المفتاحيه:فيتامين د, الفوسفاتيز القلوى, هرمون الغده الدرقيه, الكالسيوم 